\title{
Spending Standard Analysis Model for Budget Rationalization at XYZ University
}

\author{
Sarinah Joyce Margaret Rafael ${ }^{1, *}$ Moni Wehelmina Muskanan ${ }^{1}$ Sarlin Paleina Nawa \\ $\mathrm{Pau}^{1}$ Maria Prudensia Lena Muga ${ }^{1}$
}

\author{
${ }^{1}$ Department of Social Science Education, Nusa Cendana University, Kupang, Indonesia \\ *Corresponding author. Email: joyce.rafael@staf.undana.ac.id
}

\begin{abstract}
This study aims to create a Spending Standard Analysis (SSA) model as the budget rationalization policy for XYZ University. Data was obtained from Business Budget Plan (BBP) data from Faculty, Study Program, units, and sub-units of XYZ University in Fiscal Year 2019. The formulation model using linear regression analysis. The result showed five model for Spending Standard Analysis, which are for operating activities, Basic Study Skill/Student Orientations/Martikulasi Activities, Public Lecture Activities, National Seminar Activities and Workshop/Technical Guidance Activities.
\end{abstract}

Keywords: Spending standard analysis, Budgeting, Linear regression.

\section{INTRODUCTION}

Since March 2017 XYZ University switched status from Satuan Kerja or work unit to Badan Layanan Umum or Community Service Agency (CSA). CSA is an agency in the government environment that was formed with the aim of providing services to the community, both as a provider of goods and/or services sold without prioritizing profits. Activities carried out based on the principles of efficiency and productivity. The purpose of CSA is to improve services to the community to promote the general welfare and educate the life of the nation by providing flexibility to manage finances based on economic and productivity principles, and implementing healthy business practices.

According to [1] on Higher Education, in article 65 paragraph 1 mentioned "The organizer of higher education autonomy can be given selectively based on performance evaluation by the Minister to State Universities by applying the Financial Management Pattern of Public Service Agencies or by forming State Universities legal entities to produce quality Higher Education". The pattern of financial management of the CSA is regulated in [2], CSA drafted a Budget Business Plan (BBP) referring to the business strategic plan of the Ministry of State/Institution or Local Government Medium-Term Development Plan (RPJMD). BBP is structured on the basis of performance and cost accounting calculations according to the type of service taking into account the needs and capabilities of revenues expected to be received from the community, other bodies, and State Budget (APBN)/Local Government Budget (APBD). Cost accounting calculations based on these cost standards should present calculations of direct costs and indirect costs. CSA that has not compiled the cost standards set by the Minister of Finance/governor/regent/mayor in accordance with his authority. Therefore, XYZ University in drafting the BBP uses the cost standard set by the Minister of Finance contained in the Regulation of the Minister of Finance of the Republic of Indonesia No. 32 / PMK.02 / 2018.

After the enactment of CSA financial management patterns still encountered some budget weaknesses are still compiled with an incremental approach that only gives emphasis on accountability of allocated inputs only. XYZ University expenditure continues to increase dynamically without being followed by the priority scale and the size of the budget ceiling. In addition, there is an inequality in the preparation of the budget of an activity between faculties 
and study programs as well as between work units and subunits of work.

Related to the above Budget Business Plan (BBP) is used to measure performance in assessing the success or failure of activities/programs/policies in accordance with the goals and tasks that have been set. Before conducting a performance, assessment must be set input indicators first, namely funds, resources, and working methods. Input indicators can be accurately informed in a budget, so an assessment of fairness is needed. This fairness assessment between input and output is the Spending Standard Analysis (SSA). SSA is an assessment of the fairness of the burdens and costs used to carry out an activity. SSA is one of the main elements for performance-based budgeting in order to achieve economic, efficient, and effective financial management (value for money concept). Spending Standard Analysis (SSA) is regulated in [3], Article 39 Paragraph 2: "Budgeting based on work performance is carried out based on performance achievements, performance indicators, analysis of spending standards, unit price standards, and minimum service standards."

The preparation of SSA needs to be done, because there is often injustice and impropriety of spending budgets between similar activities, between study programs, between faculties, between work units, and sub-units of work. Currently there is no specific reference in budgeting activities that often appear and specifics carried out by faculty and study programs. This causes reasonable assessment of the workload and cost of activities in faculty and study programs is still varied, so this researcher will have a contribution for XYZ University in using Analysis of Spending Standards modelling for budget rationalization

\section{LITERATURE REVIEW}

\subsection{Standard Cost Analysis}

Law No. 17 of 2003 on State Finance, which emphasizes the basis of performance in budgeting, provides an important foundation for a new orientation in Indonesia. Law No. 1 of 2004 on State Treasury opens a new corridor for the implementation of performance bases in the government environment. Government agencies whose main tasks and functions provide services to the community can implement flexible financial management patterns by highlighting productivity, efficiency, and effectiveness.

The Community Service Agency is expected to be part of the implementation of financial management based on results (performance). Government regulations formed to provide services to the community in the form of the provision of goods and/or services sold without prioritizing profit and in carrying out their activities are based on the principles of efficiency and productivity.

In government regulation of the Republic of Indonesia [4] on Financial Management of Public Service Agency as amended by Government Regulation of the Republic of Indonesia No. 74 of 2012 on Changes to Government Regulation No.23 of 2005 on Financial Management of Public Service Agency, has regulated about the provisions related to financial management.

Government Regulation of the Republic of Indonesia [2], The preparation of a CSA Business plan and Budget is carried out on the basis of performance basis of cost accounting calculations according to the type of service taking into account the needs and capabilities of revenues expected to be received from the community, other bodies, and APBN/APBD. Cost accounting calculations are based on cost standards set by CSA leaders. Cost accounting calculations according to the type of service at least present the calculation of direct costs and indirect costs. In the event that CSA has not compiled a cost standard, CSA uses the cost standard set by the Minister of Finance/governor/regent/mayor in accordance with its authority. So, the BBP that has been drafted must be accompanied by the proposal of minimum service standards and cost standards.

Programs and activities submitted must be based on cost standards that present direct and indirect costs that will later improve performance achievement. Direct spending is spending that is influenced by the presence of planned activities (programmatic), while indirect spending is spending that is not directly influenced by the activities planned (programmatic).

According to [5] the performance-based budget system in every proposal and program, activity and budget must be assessed fairness. To assess the fairness of the budget of each activity using a standard cost analysis, which is the standard used to analyze the fairness of the workload or cost of each program and activity carried out in a budget year.

\subsection{Approach to Standard Preparation of Spending Analysis}

According to [6] identified there are approaches that can be used in decision making resource allocation in the public sector, namely first, a rational approach using tools such as budgets, cost-benefit analysis and statistical techniques. Second, non-rational approach such as satisfying, muddling through and garbage can model of decision making. The third expectation analysis and the fourth heuristic approach based on experience and value (experience and value). 
Ref [7] mentions three main approaches used, namely the Activity Based Costing approach, the Ordinary Least Square approach (simple regression), the Focus Group Discussion approach (discussion method).

Activity Based Costing Approach (ABC Approach). $\mathrm{ABC}$ is a cost calculation system that first traces costs to activity, then to products [8]. The ABC approach is a technique used to measure the cost and performance of activities communicatively. In addition, this approach is also used as a technique to allocate the use of resources and costs to each cost object in an activity.

In modelling the SSA's, the ABC approach aims to improve the accuracy of the cost of providing goods and services produced by calculating fixed costs and variable costs. In addition, the process of evaluating and assessing the fairness of costs with the ABC approach is not carried out based on gross allocations in an organization but based on costs per activity. The steps taken in the preparation of SSA using ABC are as follows: 1) Grouping activities with the same output in one group, 2) Determine what activities will cause costs in an activity, 3) Determining driver cost which are factors that have an effect on changes in the total cost level in an activity, or variables that cause the emergence of cost differences in carrying out a particular activity, and 4) Ordinary Least Square Approach (Simple Regression)

A simple regression approach is a technique used to construct an equation that connects a dependent variable (Y) with an independent variable (X) and to determine its alleged value with application in an SSA, a dependent variable is the total cost of an activity, while an independent variable is the cost drive of that activity. In SSA, a simple regression approach is used to create regression models (equations) to estimate spending from an activity. Assessment is done by calculating average spending, minimum and maximum spending limits, as well as the percentage allocation to each spending object. The simple regression line equation is as follows:

$$
\mathrm{Y}=\mathrm{a}+\mathrm{bx} 1 \ldots+\mathrm{e}
$$

Where $\mathrm{X}$ and $\mathrm{Y}$ are the values obtained from observation while coefficients $\mathrm{a}$ and $\mathrm{b}$ are the estimated values.

Focus Group Discussion Approach (Discussion Method).The discussion method approach in the preparation of the SSA is used to obtain input on the activities and outputs of an activity and cost drivers. This method is carried out in the hope of creating an understanding between the preparations in the modelling of the Cost Standard Analysis.

\subsection{Steps To Prepare The SSA}

Ref [7] in his writing explained 10 steps in modelling the Spending Standard Analysis (SSA). These steps are: 1) Collecting secondary data in the form of activities in the current year as well as secondary data in the form of standard unit prices, 2) Check the suitability of existing unit prices with the regulations mentioned about unit price standards, 3) Identify each type of activity about its output and driver cost, 4) Determine what activities are necessary for modelling SSA, 5) Group each activity that has the same output into one SSA group and then give the name of the SSA group, 6) Have a discussion on the initial grouping that has been made about the activity of an activity. It then agreed on improvements to the SSA groups, 7) Create a simple regression model for each agreed SSA group, 8) Calculate the minimum and maximum value of spending from the simple regression model of each SSA group, 9) Calculate the percentage of allocation to each object of spending (activity) in a SSA group, both average spending allocation, minimum and maximum spending allocation, and 10) Compiling an overall SSA guide

\section{METHOD}

\subsection{Approach and Research Method}

This research is a type of quantitative research that is systematic scientific research on its parts and phenomena and relationships.

\subsection{Type and Data Source}

The preparation of this SSA uses secondary data of Business Budget Plan (BBP) data from Faculty, Study Program, units, and sub-units of XYZ University in Fiscal Year 2019 obtained from XYZ University Planning Unit. The criteria for choosing the cost object that will be made by SSA in this study is the frequency of the activity held in each unit with the same cost component, the high budget allocation of the activity and the many price variations of each component of the cost. Based on these three criteria, researchers took 5 activities to be called SSA, namely: 1) SSA Operational Activities, with cost components: official travel expenses, honorarium, office stationery, Consumption, and other expenses. 2) SSA Basic Study Skills/student orientation/Martikulasi activities, with cost components: office stationery, Consumption, and Honorarium. 3) SSA Public Lecture Activities, with cost components: office stationery, Consumption, Travel, and Honorarium. 4) SSA National Seminar Activities, with cost components: office stationery, Consumption, Travel, Honorarium, and Building Lease and 5) SSA Workshop/ Technical Guidance activities, with cost components: 
office stationery, Consumption, official travel expenses, Honorarium, Allowance, Overtime, and Rental Costs.

\subsection{Data Analysis Method}

Before the formation of the SSA model first formed a cluster for each activity that has been selected into activities created by the SSA model. The formation of the cluster is intended so that the planned budget is adjusted to the activity of the unit.

In the stage of formation of the SSA model, using two (2) method, such as first descriptive statistic method (mean and deviation standard) to determine average value (1), upper limit value (2) and lower limit value (3) for each cost.

$$
\begin{gathered}
\text { mean }=\frac{\text { Total budget allocation }}{\text { Total data }} \\
\text { Upper limit value }=\frac{(\text { mean }+ \text { deviation standar })}{\text { total mean from each cost }} \\
\text { Lower limit value }=\frac{(\text { mean-deviation standar })}{\text { total mean from each cost }}
\end{gathered}
$$

Second method is regression analysis, used with the Ordinary Least Square (OLS) approach method as a method of forecasting fixed cost parameters and variable costs. In the preparation of this SSA, the dependent variable used is the total cost/budget of an activity, while the independent variable used is the cost driver of the activity. The allocation of spending of each cluster on activities modeled by SSA varies based on the core needs required of the activity. The regression model used is

$$
\begin{aligned}
& Y=a+b X_{1} \ldots \ldots \ldots \ldots+e \\
& Y=\text { Total budget for the year- } n \\
& \mathrm{a}=\text { Constant (Total fixed cost) year }-n \\
& \mathrm{~b}_{1}=\text { Coefficient regression (budget type) } \\
& \mathrm{x}_{1}=\text { Cost driver }(x 1) \text { per person/day } \\
& \mathrm{e}=\text { error }
\end{aligned}
$$

There are three stages in the preparation of this SSA, namely: 1) Stage I is the process of collecting BBP (Budget Business Plan) data from all units into one database. 2) Stage II is the process of grouping the activity database into several activities that have similar activity patterns and equivalent working weights and 3) Stage III is the process of forming an SSA model of an existing cluster in the same activity.

\section{RESULTS \& DISCUSSION}

In 2019 XYZ University managed a budget of Rp252.680.103.000,-. The preparation of SSA for each activity can actually be done by recalculating the amount of workload and cost of each activity based on its output, so that if there are the same activities anta Unit/Faculty with the same output with the same cost driver, the activity budget should have similarities should be relatively large (element of fairness). However, this will take a very long time. The process of preparing SSA is passed in 3 stages, the first stage is the data collection stage, at this stage from 25 Faculties and Units collected to obtain an initial picture of the various types of activities that occur at XYZ University. Second is the stage of equalization of activities, where at this stage is carried out the classification of various activities obtained from the data collection stage, at least 10 activities, into the type or catechism of activities that have similar activity patterns and commensurate work weights, equalization produces 5 kinds of activities. The third is the stage of model formation, in this stage the model of each equalization is formed to obtain an overview of the value of spending and allocation that occurs at XYZ University.

In the process of forming the SSA model obtained information about the feasibility of the model. The model is feasible when the variable cost value (B1) is significant ( $\mathrm{p}$-value $<\alpha=0,05$ ) and the model is not feasible when the value of variable cost is insignificant ( $p$-value $>\alpha=0,05$ ). Whatever the value of $\mathrm{N}$ (the amount of data), if it is significant then it is considered worth using. It's just that the goodness of the model still depends on the value of the $\mathrm{R}$-square. Low R-square values indicate that the SSA model is less able to describe the diversity of data.

A viable SSA model, summarized in a format that contains: a) code and type name of SSA, is the sequence code and type name per SSA used to facilitate users in finding the type of SSA that is in accordance with the activities to be prepared by the budget; b) Description, is an operational detail explanation of the designation of the SSA and is used to facilitate the grouping of activities carried out; c) Cost drivers are factors that affect the small amount of spending from an activity; d) Fixed cost control unit, is a spending whose value remains even though the performance target of an activity changes; e) Variable spending control unit (variable cost), the magnitude of the change in spending for each expenditure affected by changes in the volume of activities; $f$ ) The total spending calculation formula, is a formula in calculating the amount of total expenditure of an activity, this formula is the sum between fixed cost and variable cost; g) The relevant range, is a range of spending controllers so that standards can be used optimally to analyze the fairness of spending for an activity and its workload; h) Allocation of spending objects, is a table that contains details of spending objects that support an activity.

The spending object in question is a spending object that is only allowed to be used in the SSA concerned. The number of types of spending objects should not be 
increased or reduced because it is believed that the activity will only be effective if the spending objects exist. In the table of allocation of spending objects there is a lower limit proportion which is the lowest proportion of the object of spending in question, on average is the average proportion of the spending object for all Units / Faculties at XYZ University, the upper limit is the highest proportion of data used in the spending object. The purpose of the lower, average, and upper limits is to give budget users the flexibility to determine the amount of each spending object.

Based on this format, the SSA format is designed to provide spending control while providing flexibility or flexibility to its users. Spending control is indicated by the existence of a formula to determine the total spending limit of an activity based on certain performance targets and the number of types of spending objects allowed. The flexibility of budget users is indicated by the existence of data and lower limits in determining the amount of spending objects. To reduce concerns about the SSA model made from the budget of activities whose reasonableness is still questionable, the researcher will eliminate activities whose budget is unnatural, in the sense that it is not included in regression analysis, so as not to damage the SSA model that can be seen as follows:

1) SSA Operational Activities. Description of this activity group is the operational activities of Unit / Faculty / Sub unit / study program. The size of this activity is determined by the number of employees in the Unit / Faculty / Sub unit / study program in the XYZ University, so that the cost of this SSA driver is the number of employees.

The results of regressive data processing result in the following models: Fixed spending control unit (fixed cost) $=$ Rp. 150.800.000,-, Variable spending control unit $($ variable cost $)=$ Rp. $1.900 .000 \times$ total employees, Total Spending calculation formula $=$ Fixed Cost + Variable Cost $=\mathrm{Rp} 150,000,000,-+(\mathrm{Rp} 1,900,000,-\mathrm{x}$ total employees $)$

Table 1. Limitations on Allocation Spending Objects SSA of Operational Activities

\begin{tabular}{|l|c|c|c|}
\hline Spending Object & $\begin{array}{c}\text { Lower } \\
\text { Limit }\end{array}$ & $\begin{array}{c}\text { Upper } \\
\text { Limit }\end{array}$ & Average \\
\hline Office Travel Cost & $36,22 \%$ & $53,10 \%$ & $44,66 \%$ \\
\hline Honorarium & $9,77 \%$ & $12,33 \%$ & $11,05 \%$ \\
\hline Office Stationery & $21,88 \%$ & $33,79 \%$ & $27,83 \%$ \\
\hline Consumption & $0,13 \%$ & $1,04 \%$ & $0,59 \%$ \\
\hline Other Cost & $10,83 \%$ & 201,91 & $15,87 \%$ \\
\hline
\end{tabular}

In Table 1 outlined the limits of allocation of SSA operational activity objects as Table 1. SSA Basic Study Skill/Student Orientations/Martikulasi Activities. Description of this activity group is an academic activity to new students in the form of lectures that are carried out in the time before the regular lecture process begins, and carried out by the Faculty/Study Program.

The size of this activity is determined by the number of students who attend the activity and the number of days of implementation of the activity, so the cost of this SSA driver is the number of student participants and the number of days of implementation.

The results of regression watershed processing result in the following models: Fixed spending control unit (fixed cost) = Rp. 7.897.000,-, Variable spending control unit $($ variable cost $)=$ Rp. $37.000 \times$ total student $\mathrm{x}$ total days, Total Spending calculation formula $=$ Fixed Cost + Variable Cost $=\operatorname{Rp} 7.897 .000,-+(R p .37 .000,-\mathrm{x}$ total student $\mathrm{x}$ total days).

In Table 2 outlined the limits of allocation of SSA spending objects Basic Study Skill/Student Orientation/ Martikulasi activities as Table 2. SSA Public Lecture Activities. The description of this activity group is an academic activity in the form of a public lecture conducted by the Faculty / Study Program and involves sources from outside the institution. The size of this activity is determined by the number of participants who attend the activity, so the cost of this ASB driver is the number of participants of the activity.

Regression data processing results in the following models: Fixed spending control unit (fixed cost) $=$ Rp. 1.397.400,-, Variable spending control unit (variable cost) $=$ Rp. $341.800 \mathrm{x}$ total students and Total Spending calculation formula $=$ Fixed Cost + Variable Cost $=\mathrm{Rp}$ 1.397.400,- + (Rp.341.800,- x total students)

In Table 3 outlined the limits of allocation of SSA public lecture objects as Table 3. SSA National Seminar Activities. The description of this activity group is an academic activity that is a national seminar conducted by faculty / study programs and involves speakers from outside the institution. The size of this activity is determined by the number of participants who attend the activity, so the cost of this SSA driver is the number of participants of the activity.

The results of regressive data processing result in the following models: Fixed spending control unit (fixed cost) $=$ Rp. 1.397.000,-, Variable spending control unit (variable cost $)=$ Rp. $341.700 \times$ total participants, Total Spending calculation formula $=$ Fixed Cost + Variable Cost $=R p$ 
1.397.000,- + (Rp.341.700,- x total participants), In Table 4 outlined the limits of allocation of SSA spending objects to the National Seminar as Table 4.

SSA Workshop/Technical Guidance Activities. The description of this activity group is a workshop or technical guidance which is an activity to provide workshop/technical guidance to employees or lecturers at XYZ University to obtain certa1technical skills that are operational in nature related to the main needs of units/ faculties/subunits/study programs. The size of the workshop/technical guidance is determined by the participants of the activity and the length of the activities carried out so that the cost driver of this SSA is the number of workshop/technical guidance participants and the number of days of implementation.

The results of regressive data processing result in the following models: Fixed spending control unit (fixed cost) $=$ Rp. 13.000.000,-, Variable spending control unit $($ variable cost $)=$ Rp. $113.300 \times$ total participants $\times$ total days and Total Spending calculation formula $=$ Fixed Cost + Variable Cost $=$ Rp 13.000.000,- + $($ Rp.113.300,- $\mathrm{x}$ total participants $\mathrm{x}$ total days). In Table 5 outlined the limits of allocation of SSA Workshop/Technical Guidance objects.

Table 2. Limitations on Allocation Spending Objects SSA of Basic Study Skill/Student Orientations/Martikulasi Activities

\begin{tabular}{|l|l|l|l|}
\hline \multicolumn{1}{|c|}{ Spending Object } & $\begin{array}{r}\text { Lower } \\
\text { Limit }\end{array}$ & $\begin{array}{r}\text { Upper } \\
\text { Limit }\end{array}$ & Average \\
\hline Office Stationery & $57,08 \%$ & $60,08 \%$ & $58,58 \%$ \\
\hline Consumption & $29,09 \%$ & $30,58 \%$ & $29,84 \%$ \\
\hline Honorarium & $10,79 \%$ & $12,38 \%$ & $11,58 \%$ \\
\hline
\end{tabular}

Table 3. Limitations on Allocation Spending Objects SSA of Public Lecture Activities

\begin{tabular}{|l|c|c|c|}
\hline Spending Object & $\begin{array}{c}\text { Lower } \\
\text { Limit }\end{array}$ & $\begin{array}{c}\text { Upper } \\
\text { Limit }\end{array}$ & Average \\
\hline Office Stationery & $13,43 \%$ & $14,99 \%$ & $14,21 \%$ \\
\hline Consumption & $19,08 \%$ & $20,71 \%$ & $19,90 \%$ \\
\hline Travel Expenses & $38,18 \%$ & $44,35 \%$ & $41,26 \%$ \\
\hline Honorarium & $23,34 \%$ & $25,92 \%$ & $24,63 \%$ \\
\hline
\end{tabular}

Table 4. Limitations on Allocation Spending Objects SSA of National Seminar Activities

\begin{tabular}{|l|c|c|c|}
\hline \multicolumn{1}{|c|}{$\begin{array}{c}\text { Spending } \\
\text { Object }\end{array}$} & $\begin{array}{c}\text { Lower } \\
\text { Limit }\end{array}$ & Upper Limit & Average \\
\hline $\begin{array}{l}\text { Office } \\
\text { Stationery }\end{array}$ & $24,39 \%$ & $25,96 \%$ & $25,17 \%$ \\
\hline Consumption & $19,52 \%$ & $21,80 \%$ & $20,66 \%$ \\
\hline $\begin{array}{l}\text { Travel } \\
\text { Expenses }\end{array}$ & $27,60 \%$ & $29,06 \%$ & $28,33 \%$ \\
\hline Honorarium & $9,52 \%$ & $10,21 \%$ & $9,87 \%$ \\
\hline $\begin{array}{l}\text { Building } \\
\text { Lease }\end{array}$ & $5,83 \%$ & $6,67 \%$ & $6,25 \%$ \\
\hline Publication & $8,99 \%$ & $10,08 \%$ & $9,54 \%$ \\
\hline
\end{tabular}

Table 5. Limitations on Allocation Spending Objects SSA Workshop/Technical Guidance Activities

\begin{tabular}{|l|c|c|c|}
\hline \multicolumn{1}{|c|}{$\begin{array}{c}\text { Spending } \\
\text { Object }\end{array}$} & $\begin{array}{r}\text { Lower } \\
\text { Limit }\end{array}$ & $\begin{array}{r}\text { Upper } \\
\text { Limit }\end{array}$ & Average \\
\hline $\begin{array}{l}\text { Office } \\
\text { Stationery }\end{array}$ & $14,66 \%$ & $19,35 \%$ & $17,01 \%$ \\
\hline Consumption & $27,74 \%$ & $33,48 \%$ & $30,61 \%$ \\
\hline $\begin{array}{l}\text { Office Travel } \\
\text { Expenses }\end{array}$ & $20,85 \%$ & $36,63 \%$ & $28,74 \%$ \\
\hline Honorarium & $13,42 \%$ & $25,27 \%$ & $15,94 \%$ \\
\hline Allowance & $4,23 \%$ & $8,32 \%$ & $6,27 \%$ \\
\hline Overtime & $0,14 \%$ & $0,43 \%$ & $0,29 \%$ \\
\hline Rental Fee & $0,34 \%$ & $1,96 \%$ & $1,15 \%$ \\
\hline
\end{tabular}

\section{CONCLUSION}

The results of this research conclude as follows: (1) SSA is an important tool for university management to apply the principle of value of money in the internal control system to the university's financial management; (2) SSA must be done and updated every year by following budget changes due to inflation; (3) There are several important criteria in determining the activities that must be made by SSA as a form of implementation of the principles of fairness and budgeting, namely: the frequency of such 
activities held in each unit with the same cost component, the high budget allocation of the activity and the many price variations of each component of the cost; (4) The above criteria must be reviewed by the University Planning Unit every year to accommodate the activities that must be made by SSA to minimize deviations due to weak cost control; (5) This study produced 5 activities that have met the criteria at point 3 (three), namely: (a) SSA Operational Activities, with cost components: office travel expenses, honorarium, office stationery, consumption, and other costs. (b) SSA Basic Study Skills/Student Orientation/Martikulasi activities, with cost components: office stationery, Consumption, and Honorarium. (c) SSA Public Lecture Activities, with cost components: Office Stationery, Consumption, Travel, and Honorarium. (d) SSA National Seminar Activities, with cost components: Office Stationery, Consumption, Travel, Honorarium, and Building Lease. (e) SSA Workshop/Technical Guidance Activities, with cost components: office stationery, Consumption, Office Travel Expenses, Honorarium, Allowance, Overtime, and Rental Costs.

This SSA calculation is expected to be applied thoroughly at XYZ University by issuing the Rector's Regulation on SSA, which can be started from Budget Year 2020. The application of SSA in government institutions has been regulated in [3], Article 39 Paragraph 2: "The preparation of budget based on work pretense is carried out based on performance achievements, performance indicators, analysis of spending standards, unit price standards, and minimum service standards.

\section{REFERENCE}

[1] Pemerintah Republik Indonesia, Undang- Undang No 12 tentang Pendidikan Tinggi. Indonesia, 2012.

[2] Pemerintah Republik Indonesia, Peraturan Pemerintah Republik Indonesia Nomor 74 tentang Pengelolaan Keuangan Badan Layanan Umum. Indonesia, 2012.

[3] Pemerintah Republik Indonesia, Peraturan Pemerintah Republik Indonesia No 58 tentang Pengelolaan Keuangan Daerah. Indonesia, 2005.

[4] Pemerintah Republik Indonesia, Peraturan Pemerintah Republik Indonesia No 23 tentang Pengelolaan Keuangan Badan Layanan Umum. Indonesia, 2005.

[5] W. Kumorotomo, Penganggaran dan Penilaian Kewajaran SAB. Yogyakarta: Universitas Gadjah Mada, 2007.
[6] Z. Y. Zhuang and P. M. Collier, "Resource Allocation Decisions in the Public Sector: A Model Based on a Study of Policing," 2010.

[7] A. H. Tanjung, "Peranan dan teknik Penyusunan Analisis standar belanja dalam penyusunan APBD," Pelalawan Riau, 2010.

[8] D. R. Hansen and M. M. Mowen, Managerial Accounting, 8th ed. Boston: South-Western College Publisher, 2005. 